\section{MAKING THE SECOND NATURE: TOWARDS A CRITIQUE OF CULTURAL POLITICS IN URBAN PERCEPTION - THE USA CONTEXT, 1850-1940s}

\author{
Güven Arif SARGIN
}

Received: 06.12.2010; Final Text: 22.03.2011

Keywords: Nature-City dichotomy; Arcadian vision; industrial capitalism; metropolis and cultural politics; urbanism in the USA.

1. For a detailed discussion on the spatial history of American environmental design discourse, please refer to Sargin (1996); and for the political syntax of the ideal Middle Landscape, Sargin (1997).
As manifested in the original Marxian tradition, environmental transformation is a complex process that necessitates a symbiotic metamorphosis of nature and society (1). It is therefore a social process; and the agencies' interaction with nature, their mental conceptions and such perceptive experiences are shadowed under politics (Sargin, 2000) Politics is the most assertive realm of change, being thoroughly instrumental in nature's formations, deformations and its spatial and cognitive displacements. It can be said that politics, as a meta-narrative and ideology and the legitimizing apparatus of such narrations, not only transforms nature, but also fabricates the cultural sphere within which such transformations become publicly possible, making the whole processes either significantly legal and recognized, or illegitimate and discrete. The mode of urbanism of the early 1900s in North America in this context deserves special attention, as the state's desire for modernization presents a similar cultural sphere by which urban programs and their spatiality reflect an environment of revolution in relation to the nation's ideological choices. The idyllic constructions, the emerging industrial capitalism and the related urban utopias demystify how the state, as well as the national bourgeoisie, drew out their ideological mappings and conceived nature in their imagined inventions.

The Arcadian vision and industrial urbanism have together developed a basic cultural premise and produced the most outstanding results since the late nineteenth century - the Arcadian view established a strong sentiment towards nature, while progressive urbanism represented a peculiar transition from laissez faire to industrial capitalism; and the continuous clash between the two became a powerful metaphor for social change that symbolized the ideal city and the vast open countryside, the liberty of urbanism and the virtue of rural spirit, and the revolutionary power of modernity and the tradition of frontier culture. The transformation of bare landscape into a metropolis had always been an important process that also represented an intellectual debate. In this rivalry, however, space was 
regarded in the acceptance of the dichotomy of the city and countryside not as a conclusion, but as a point of departure for the development of a political strategy of reconciliation (Cronon, 1992). There, it was first the frontier culture that was identified with the boundless immensity and emptiness, or ahistorical character of the New World, the New World in the Puritan belief represented nothing but wild, raw nature, a cultural vacancy untouched by history that was waiting to be cultivated. Secondly, it was the primitivist culture that created a nature-oriented aesthetic form in which wilderness was believed to be the center of life- it was indeed an unsystematic critique of organized society, in particular of industrial capitalism. The final core was the pastoral version, which was favored by a much larger population as a battlefield for nature and culture. The hundred-year contrast between the two worlds -one identified with the simple mode of countryside and rural peace, the other with the power of urban life, sophistication and chaos- became the dominant intellectual mode in creating a symbolic landscape, believed to be a delicate blend of myth and reality (Marx, 1967).

In Jefferson's notes, the New World as a Virgilian pasture was believed to have provided an ethical sphere that was built upon a philosophy of nature, and taming the wilderness was a significant dimension of this, closely associated with the true American identity. The family farm provided the images, and agriculture was to guarantee the properties of American morality in the new republic. Jefferson's political syntax attempted to find a precise central point between the old European regime and the new egalitarianism, and the rural virtue was certainly the moral locus for the creation of a democratic society with economic self-sufficiency. As Beard argues, "in spite of all the difficulties and discouragement confronting the American people, land is the real basis of democracy, the only genuine and enduring basis ... it stands on an independent foundation" $(1949,347)$. Rural life and the rights of individual property as a moral seed could overcome the problems of industrial capitalism and a market-regulated society. It was an attempt at ideal governance, as the capitalist city had been deemed undesirable in urban industrial life in the Old World where it was believed to have been the real cause of both environmental and social ruin, i.e., the landed interests of course formed the overwhelming majority: "it is not so evident that ... Jefferson, so cordially cherished the laboring interests of the cities. On the contrary, Jefferson repeatedly and with great deliberation, declared ... a profound distrust of the working-classes of the great cities" (Beard, 1949, 421). The distrust of the working class and commerce, and the romantic devotion to a pastoral myth, in particular to the role of agriculture, resulted in an ideological position between agrarianism and capitalism. The developing pressure of American industry, however, created a fundamental conflict between capitalistic and agrarian interests, and industrial development soon triggered enormous growth in the economy. As a result, the continental landscape was slowly turning into a garden imagined with a massive industrial wealth. The gradual dominance of capitalism also changed the modes of urbanism; however, it was not so radical that the traditional agrarian town suddenly became an urban-industrial metropolis - being rather slow and competitive. As a spokesperson of American Transcendentalism, for instance, Emerson combined capitalism with a romantic love of nature, blending popular American pastoralism with post-Kantian philosophy. He made a clear distinction between the two faculties of the mind: understanding and 
2. According to Thoreau, if natural facts were properly perceived and accurately transcribed they would yield the truth, the ultimate relation between human with nonhuman. Thoreau's romantic experience of Walden, in that sense, presents an American moral vision of living by observing the ways of nature (Thoreau, 2004). reason, in which city life was a perfect environment for understanding, and reason required a rural scene. According to Emerson, the advance of civilization can technically teach human beings to understand the factual aspects of life; but it is in the countryside that they can grasp the sublime. The countryside was a center from which the moral sphere could emerge, and it was the cities that could degenerate the rural virtue. Henry Thoreau followed a similar line, withdrawing from the practices of industrial society in the direction of nature. In the late-nineteenth century, Thoreau increasingly influenced the biocentric, Arcadian view. Being a romantic naturalist of his time, he defended biocentrism in which non-human natural objects were recognized as having intrinsic value, independent of human consideration (Miller, 1981)(2).

All these discursive formations gave way to visually rich images, suggesting that idyllic environments in the age of capitalist development were still possible; however, this came with all the social conflicts and the complex systems expected with contradictory interactions and interests, rather than the harmonies of its culture. Historically, the new republic was overwhelmingly rural in its first decades and its condition was believed to be truly American. With industrial development, the city then became an ideological domain - if rural America was at the center of the Arcadian ideal, then urbanism was a threat to the moral locus of the American ideal, through which the industrial urban environment was regarded as a symbol of the declining agrarianism (Reps, 1989). Nevertheless, the city was an indispensable part of American capitalism - the advanced factory system was a necessary feature of technological progress, which in reality needed a complete shift from the small agrarian workshops to the machine-based modern factory. For the workshop, as an instrument of rural life, the factory meant a total transformation; but industrialization and factories, the very tools of capitalist enterprise, were soon accepted and adopted by the agrarians in order to combine the power of technology with the art of nature. Of many works, it was Carl Bridenbaugh (1938) who most broadly questioned the foundations of American urban life and its transition from predominantly rural agricultural towns to nineteenth-century industrial metropolises. In his work, Cities in the Wilderness, the American city was an expression of the pursuit of economic growth through social equality in which the progressive social and political organizations largely enjoyed the benefits of the city. In short, urbanization was an instrument for political purposes, "when Marx and Engels said that towns saved people from the idiocy of rural life, they were endorsing the widely accepted correlation between urbanism and emancipation" (Short, 1991, 43).

\section{FROM UTOPIAN COMMUNITIES TO SCIENCE-FICTION METROPOLISES}

As early as the 1850s, capitalism began to take shape as a part of the general theme of American popular culture, and thus the philosophy of nature was transformed into a moral struggle, having a political sphere for exploring the national identity - nature teaches the great ideals of liberty, justice and equity, but it is in the city that these could provide the ethical principles of the true American democracy. This romantic revival not only inspired intellectual circles, but also more directly developed a particular urbanism that was unique to American culture. Two patterns hence were of significance: utopian communities and rural cemeteries. Although the idea of the community was always of prominent importance, it was in 
3. The European communities could not develop an alternative environment free from the forces of capitalist production; rather, they emerged as an extension of the middle class vision: "the criticism of ideology as a whole and, above all, the Marxian theory of value have demonstrated that utopia is ultimately not an alternative to the organization of the class struggle but a design for the orderly progress and possible planning and programming of productive forces" (Dal Co, 1979, 149).

4. Rural architecture was akin to examples from the eighteenth century, of which the University of Virginia campus was a good example - an ideal landscape with distinctive design syntax, specific to Jefferson's agrarian image. The University of Virginia is one of the best examples of the American rural architecture in that it truly represented the Federal Period of 1790-1820; i.e., the perfect blend of the Greek revival architectural style within a pastoral climate, that of "Jefferson the political philosopher" and "Jefferson the architectural critic," at the same time (Andrews, 1967, 60).

5. The popular response to rural cemeteries was unexpected and probably undesired. In one nine-month period, Downing noted that more than 30,000 people visited Laurel Hill, and supposedly nearly twice that visited Greenwood. Local entrepreneurs quickly responded by selling guidebooks and descriptive brochures that helped choose the most attractive routes, and chronicled the background of each person buried on a monument-by-monument basis. Street railways extended their lines to meet the demand and extra cars were run out to the grounds on weekends. In an act of self preservation, most of the cemeteries had to pass strict rules regarding times of access, prohibition of picnics and fishing, and the limitation of concessions and alcoholic beverages (Steward, 1973, 87-8). the seventeenth century that such experiments began in America. It is important here to emphasize that the utopian projects in America were different to their European successors in their preference for the notion of nature. The utopian projects of nineteenth-century Europe can be regarded as the nexus of modern urbanism, and the socialist communities were rather political symbols promoting an alternative lifestyle that would eventually rival the traditional bourgeois city and the system of capitalist development (3). According to Dal Co: "the libertarian tradition, evolved in the New World by social groups who had suffered religious persecution in Europe, created conditions more favorable to utopian experiments. Second, the socialist derived utopias, transplanted from Europe to the United States revealed even more clearly their limitations and the abstractness of their conception than they had in Europe. In addition, the American utopia did not have to oppose a formal tradition as strong as that of the bourgeois European city; instead, it took its place within the native tradition, resuming and rationalizing the schemes of the earliest settler's free communities" $(1979,150)$. If the utopian community was essentially part of an emerging modern urbanism, the rural cemetery was also a prelude to the new urbanism that was to come (4). The modern cemetery had become a concern of several New England cities "as a response to the public health fear of continued burial of large numbers of people within the urban area in close proximity to the water supplies, often still derived from nearby shallow wells" (Steward 1967, 84). The Mount Auburn cemetery in Cambridge, which opened in 1831, was the first such example. Located six miles from Boston, its immediate success encouraged the establishment of similar cemeteries in other cities, such as Greenwood in Brooklyn, Laurel Hill in Philadelphia, and others in Baltimore, Rochester and Albany. It was an elegant example following the picturesque principles of the English Landscape School in achieving a naturalistic effect, decorated with Classical and Victorian elements in its tombs, monuments, temples and other sculptural edifices. The overall effect was a perfect blend of natural beauty and melancholic sentiment that later became a major characteristic of American romantic urbanism (5). There was a growing tendency towards nature that was of course mostly driven by cultural reasons - the influence of the Transcendentalist literary mode and religious motivations that brought up to date the American myth of nature. The naturalistic décor was in a greater sense a romantic escape within the metropolis; a dream that ideologically expressed the urbanite's hope for ultimate peace. They were accepted as rational, efficient and beautiful, where the formal teachings of the romantic pastoral ideal were integrated into a system of new urbanism that was believed to be genuine to American culture. It was indeed a complex cultural expression of the growing taste for the American picturesque; with the eclectic character of its architecture, its romantic layout and the attempt to integrate the general layout into nature being some of the key elements used to achieve this task.

These rural utopias and cemeteries were the beginnings of the new urbanist attitude being pioneered by Andrew Jackson Downing, who having first been involved in horticulture, went on to develop the principles of picturesque urbanism to come. His major literary work, Landscape Gardening and Rural Architecture, published in 1841, combined the romantic American spirit with the scientific attitude of the horticulturist world, and became one of the most significant texts of its time, in which an organic aesthetic of design and picturesque urban landscaping was defined, making a substantial contribution to the creation of an eclectic 
6. However, Downing's major interest was the improvement of a form of country residence, while his picturesque aesthetic stressed the essential harmony of domestic architecture, blending comfortably into its natural setting. For him, "Architectural beauty must be considered conjointly with the beauty of landscape or situation" (Downing 1991, 320). language. Drawing influence from the Romantics, the Transcendentalists and the Unitarians, Downing believed that one could overcome the problems of both the natural and built environments while expressing a unique aesthetic tendency - with the "the love of nature and science." As he so elegantly expressed in his book, aesthetic taste would affirm precisely such values as "the love of order, the obedience to law, the security and repose of society, the love of home" upon American culture (Bender 1975, 162)(6). His expression of a common picturesque urbanism and the relative distrust of the industrial metropolis provided an aesthetic choice of romantic revivalism, "it is this love of rural, and this nice feeling of the harmonious union of nature and art, that reflects so much credit upon the English as a people, and which, sooner or later, we hope to see completely naturalized in this country" (Downing 1991, 352). Harboring a political tone, his ideas represented, to a great extent, the basic framework of Jeffersonian politics. He was convinced that the idea of community in nature would be the essential element of American democracy, "our rural residences, evincing that love of the beautiful and the picturesque, which, combined with solid comfort, is so attractive to the eye of every beholder, will not only become sources of the purest enjoyment to the refined minds of the possessors, but will exert an influence for the improvement in taste of every class in our community" (Downing, 1991, 352).

It was, however, Frederick Law Olmsted who contributed to this tradition in full accord. Suggesting the abandonment of the capitalist competitive lifestyle that was increasingly dominating cultural practice, Olmsted went back to the origins of the city, believing that the urban parks and suburbs would work as stabilizing forces in metropolises. His desire for the creation of a non-competitive, yet organic-urban community gradually increased during his extensive travels to the south and the west; but long before his first southern journey, Olmsted visited the utopian North American Phalanx, near Red Bank, New Jersey. Although he was impressed with this "Fourierist community established by Albert Brisbane in 1843, he thought that certain things like educational opportunities which a city could offer were largely missing in this settlement" (Bender, 1975). He seemed to be convinced that it was urban life, not rural, that would provide opportunities for an egalitarian society. His opinion of social democracy, however, was reinforced mainly during his visit to the south, where he compared the southern states on the basis of essentially urban and industrial standards. For Olmsted, the southern cities were small, inferior and dirty -public facilities and green areas were lacking, and furthermore, the idea of industrial development had no or little importance in public life (Roper, 1983). For many, if his opposition to slavery as a form of labor was basically economic, his criticism of slavery as a social system was due to his political choice- from his moral commitment to social democracy. During the Civil War, Olmsted decided that the future was within the city; however he strongly believed that American urbanization had a fundamental flaw, being a lack of "happiness," and from this he deduced that cities must satisfy social needs as well. From this partial account of his interests, "his ties with the utopian tradition, particularly Fourierism, his relationship with such exponents of the Unitarian faith, and, finally, his decided stand against slavery make Olmsted a typical figure of American progressivism" (Dal Co 1979, 160). His success actually lay in his ability to transform the dominant design genre, the utopian communities, the rural cemeteries and the Transcendentalist literary debate, into a unique urbanism; and his Central Park project was believed to be the most 
7. In 1851 a design competition was held in which thirty-five designers participated. In 1858 Olmsted and Vaux's "Greensward" project won the first prize, and Olmsted was appointed as the chief architect. The Central Park project was of paramount importance due to its qualities in large scale. For Mumford, "Olmsted had done something more than design a park, battle with politicians - he resigned at least five times, struggle with insolent and rascally city appointees and project his fantasies against vandals: he had introduced an idea - the idea of using landscape creatively. By making nature urbane, he naturalized the city" (Dal Co, 1979, 162).

8. The designer's main intention was to cultivate the nature according to picturesque principles. In its first years of construction, an impression of natural beauty was achieved: "more than 1.1 million cubic yards of earth were excavated and moved on the site, nearly two hundred thousand cubic yards of stone blasted or otherwise rearranged, and approximately fourteen thousand barrels of cement were used to construct various improvements." All of this eventually required a massive labor activity of more than "15,000 laborers employed" (Steward, 1973, 200). astonishing example of his career in this transformation (7), being both an urban park and a strong political act. Ironically enough, the intended result was entirely unnatural, aimed at making the site appear as natural as possible (8) For Fein (1972), however, it was the relationship between the park and the city that made the project a milestone in contemporary urbanism. The Central Park project indeed enhanced the common tendency of what the rural cemeteries and the Arcadian utopias had aimed to achieve, and also provided a contrast to the image of industrial capitalism.

Metropolitan urbanism, for Olmsted, was synonymous with justice as well as with participation in the democratic process. Nature had to be accessible to all, including the proletariat, to be a place where everyone could come together in a democratic but refined order. Thus, parks as a political means were a great opportunity to educate the less privileged about their collective responsibility; and in this regard they were a symbol of a united community. Despite his political simplicity, Olmsted truly believed that his parks were ideal and active expressions of nature, and his priority was to give rise to a romantic aesthetic theory. Following a similar line to his urban parks, suburbia could also be regarded as a typical expression of the true American democracy. Industrial urbanism led to a drastic separation of work and residence, to congestion, and to the division between city and country. In Olmsted's view, "all these problems could be resolved through the efficient planning of urban services, an adequate use of technology, and the creation of suburban neighborhoods, not cut off from the city and provided with all these necessary services" (Dal Co, 1979, 165). Suburbanurbanization for the metropolitan areas seemed to have had provided the best instrument for taking advantage of modern urban life and natural beauty. However, the suburb itself was not an anti-urban instrument, but was rather an attempt to cope with the demands of metropolitan life, providing a setting for domestic life, free of the problems that characterized the industrialization of the nineteenth century. The Llewellyn Park project of Olmsted and Vaux was America's first planned romantic suburb around Newark, New Jersey, and it is still important for two reasons: "First, it reflects Olmsted's and Vaux's regard for that achievement, which served as a prototype for all their future efforts to plan communities; second, it emphasizes the fact that the parkway was more then merely an alternative to the ordinary city street. It was designed also as a route to a specific place: the planned community" (Fein, 1972, 32). The idea of a planned community was revolutionary, in that it united rather than fragmented the city with the countryside. According to Olmsted, the spreading industrial city was ultimately "destructive, socially and physically to all environmental forms". For him, there was "no technical reason why the suburb should not combine the best features of city and country" in order to promote a healthy environment and protect the countryside (Fein, 1972, 32-3). Similar principles were put into implementation in Riverside (186869), which was planned not as a mere urban utopia, but rather as a natural and necessary outgrowth of metropolitan Chicago in which all of the public services and facilities that made the city attractive would also be readily available to its inhabitants - from public laundries to recreational activities; and from sewer, gas and water to the provision of other daily services, all of which were important parts of the project. The overall idea was, in contrast to the sense of alienation that characterizes the Gesellschaft of a city, an integrated society embodying the sense of Gemeinschaft -perhaps a "Gemeinschaft of the privileged. Riverside, however, still remains as one of America's foremost examples of nineteenth-century urbanism, and was a 
9. Although a series of serious measures had already been taken in this period, the years between 1870-1890 witnessed initial efforts in the creation of such great national parks as Yellowstone and Yosemite. In 1872, Congress approved the first major reservation of federal land when it created the 2-million-acre Yellowstone National Park in the first systematic effort to protect federal lands, as embodied in the Forest Reserve Act of 1891. President Harrison, working in accordance with the act, created fifteen forest reserves with a total area of 13 million acres; and, six years later, President Cleveland signed up for another thirteen new reserves, totalling over 21 million acres (Shabecoff, 1993). Gifford Pinchot and John Muir, among others, played a key role in this nation-wide campaign. Most importantly, the conservation movement later had a significant influence on the twentieth century regionalism favored by some. For both conservationists and regionalists, nature was no longer a romantic ideal, but a means to efficiently use the power of the nation's economy in which the principal concern was 'planning' for efficiency, discipline and productivity, modifying the ways of economic growth and the management of the capitalist system.

10. Under his administration, resources were not un-limited, and needed scientific, rational methods of protection for the future: "conservation, above all, was a scientific movement, and its role in history arises from the implications of science and technology. Its most important contribution ... was the introduction of applied science and professional management to the development of natural resources" (Shabecoff, 1993, 69).

11. "In the course of 54 years, from 1860 to 1914 , the value of the national industrial product had grown by roughly factor of twelve, and the number of wage earners increased five and a half times over. In 1860-1910, while the total population grew by 193.2 percent, the number of urban residents increased by 575,6 percent. During the same fifty years the population of

New York increased six times over; that of Chicago, twenty times, and that of Pittsburgh, from 49,221 to $1,044,143$...The era of the automobile began in 1911; between 1915 and 1929 the number of motor cars registered increased from 2,300,000 to $23,100,000$, and the economic boom was founded on this field of production. The automobile stimulated a whole series of important phenomena, including the territorial diffusion of settlements, the development of suburbs, and the construction of new roads" (Dal Co, 1979, 184-6). milestone along the road to the idea of the garden city. For some, however, the Colombian Exposition in 1893 was in fact an ideological messenger of a changing era in urbanism and Olmsted's main concern over the landscape and cityscape in city planning was in deep question. As a result, Olmsted's work was not fully rediscovered until 1930.

\section{TOWARDS A GREEN PROGRAM: ENGINEERED URBANISM}

The turn of the century was a breaking point for "accepting the idea that even democracy needs of plans," and eventually the Progressive Era would gave rise to a comprehensive model to accomplish that ideal (Dal Co, 1979, 178). The importance of the Progressive Era, however, lies within the notion of conservation that originated back in the mid-nineteenth century, when the central principle was to safeguard natural resources, and when the utilization of the nation's powerful resources, from hydroelectric to agriculture, was of utmost importance in the political agenda (9). In the early years of the twentieth century, President Theodore Roosevelt, whose administration established the foundations of modern environmentalism in America, was regarded as the first and greatest conservation-minded president owing to his keen policies to preserve public lands and resources. He was a practicing environmentalist, who, during his administration, followed the dual policies of the efficient use of natural resources and their protection. This was a direct challenge to the prevailing notion developed under Arcadian ideology that America's resources were inexhaustible (10). Perhaps the greatest legacy of Roosevelt was his emphasis on conservation as an important means of protecting true American democracy. The Jeffersonian ideal of nature was systematically fused into his environmental policy. For him, protecting nature was necessary for the sustainability of egalitarian policies in America; and the resources in the public domain, therefore, were not to be used only for the benefit of the economically privileged, but for all Americans. This meant the efficient use of the nation's resources with the objective of economic growth, the safeguarding of jobs and the protection of national security. However, neither the public nor the government, while increasingly sympathetic to conservation, would shut out the motors of economic activity. As the Progressive Era was witnessing the application of radical environmental measures, the idea of natural conservation was becoming a new perception in the world, and would become one of the most effective instruments of contemporary urbanism. In sharp ideological contrast, the Progressive Era in fact was a genuine attempt to combine the romantic environmental concern with the required capitalist growth; however the transformation of the Jeffersonian agrarian order into industrial urban America was not that simple. Capitalism was in need of further development, and so technological improvements and massive urbanization gave rise to an economic system that eventually accelerated an aggressive speculation of land (11). This new progressive spirit found a definite political discourse through Roosevelt's New Nationalism speech of August 31, 1910, in which he expressed the principal elements of his doctrine - first, federal control over economy; and second, the increasing role of public institutions in social issues.

Roosevelt's administration took significant measures in urban issues that may be considered as the first manifestations of a long-term project for progressive urbanism. It was in fact the garden city that was the most directly attractive step, owing to a policy based upon the legacy of 
12. "A society where each individual is a producer of both manual and intellectual work; where each able-bodied human being is a worker, and where each worker works both in the field and the industrial workshop where every aggregation of individuals, large enough to dispose of a certain variety of natural resources - it may be a nation, or a region - produces and itself consumes most of its own agricultural and manufactured produce" (Kropotkin, 1974, 26).

13. Howard's proposal was a city of 32,000 people in 5,000 acres in the countryside, far enough from the city. Each garden city, was to contain not merely farms, but also urban institutions, and offer a wide range of jobs and services connected to the other centers via a transit system; thus giving all the economic and social opportunities of a traditional city (1966)

14. According to Mumford, "what was needed, Howard saw -as Kropotkin at the same time proclaimed- was a marriage of town and country, of rustic health and sanity and activity and urban knowledge, urban technical facility, urban political co-operation. The instrument of that marriage was the Garden City" $(1965,34)$

15. "In the first place, the garden city was in keeping with decentralist theories that received considerable support from the progressivists in their fight for a policy capable of resolving the problems of congestion. Second, the garden city was considered an effective model for attracting the financial interest of business enterprises, because of the stable yield it guaranteed, the possibility it offered for enlarging the realestate market, and the means it provided for removing the labor force from urban unrest. Third, as a new and entirely planned city and a programmed formula for its management, the garden city made possible not only a series of economies that permitted the realization of higher residential standards but also the definitive integration of the housing problem and the planning operation" (Dal Co, 1979, 211)
Ebenezer Howard, who at that time was the single most important figure in the town planning movement in Europe. By 1902, his first seminal publication, Garden Cities of To-morrow, advocated his theory as a means for the progressive reconstruction of capitalist society into a co-operative oriented social structure (1966). For Howard, garden cities were not merely colonies for the urban poor; but "were to be founded, and managed, by the stratum immediately above ... who were thereby to be freed from the thralldom of the urban slum. His solution was not paternalistic - at least apart from some residual undertones; rather, it belonged firmly in the anarchist tradition" (Hall, 1990, 90). Some of his ideas, such as that new technologies would permit the dispersal of the urban population of industrial cities were certainly influenced by Peter Kropotkin, who, in his seminal work Fields, Factories and Workshops, published in 1898, promoted the creation of small towns of limited populations with surrounding agricultural green areas. Carefully assessing the impact of capitalism during the industrial revolution, Kropotkin also proposed small-scale workshops as an attempt to create self-governing units in which agriculture and workshops were complementary. According to him: "agriculture calls manufactures into existence, and manufactures support agriculture. Both are inseparable; and the combination, the integration of both brings about the grandest results" (Kropotkin, 1974, 25). Rather than a strict division of labor, Kropotkin believed that the integration of labor would maintain the ideal society; a society of integrated, combined labor (12). His ideal settlement was therefore a choice of the pre-capitalist period, where the feudal villages and towns carried small industries in connection with agriculture - "industrial villages". There is no reason why small industries again could not belong to the community, since the economic tendency had pronounced a new type of settlement pattern, "such facts, as well as the pronounced tendency of the factories toward migrating to the villages... which become more and more apparent nowadays, and found of late its expression in the 'Garden Cities' movement, are very suggestive", argues Kropotkin $(1974,151)$. He also suggests that "[we] have the factory and the workshops at the gates of your fields and gardens, and work in them ...", which would provide "a rich vegetable food and a profusion of fruit, if they simply devoted to the task of growing them the hours which everyone willingly devotes to work in the open air, after having spent most of his day in the factory, the mine or the study. Provided, of course, that the production of food-stuffs should not be the work of the isolated individual, but the planned-out and combined action of human groups" $(1974,194)$. However, unlike Kropotkin, Howard rejected socialist-oriented centralized management and the subordination of the individual to the group. The garden city, for him, was not a bourgeois suburb, nor politically a more rural retreat, but a more integrated foundation for an effective urban life. The key issue in the urban problem, as he claimed, was to restore "the people to the land - that beautiful land of ours, with its canopy of sky, the air that blows upon it, the sun that warms it, the rain and dew that moisten it" $(1965,44)$. In fact, his ideal urbanism was a "Social City," combining the best of town and country in a new kind of settlement - Town-Country (13). Howard paid more interest to social processes; because for him, what a garden city would offer was a third yet unique socio-economic system based on local management and self-government, superior both to Victorian capitalism and to Bureaucratic centralized socialism (14).

Creating a new socio-economic order via quasi-urban settlements was a unique American vision (15), and was quickly accepted as an alternative 
16. He began his professional career in the early 1900s, and during the 1910s and 1920s he was one of the most successful urbanists in the country, soon becoming a major figure in the New Deal years. Throughout his career, Nolen produced a vast number of works, including the planning projects of San Diego, Montclair, and Madison-Wisconsin.

17. For Nolen, Madison as a model city was one of the most striking places because it captured a unique identity that was based upon the topography of Wisconsin's unique wilderness. "Topographically," he believes, "Madison naturally abounds in interest and picturesque situations" (1911, 19). Here, he concludes that "in a marked typed topography and natural scenery, in the conscious establishment of a city for governmental and higher educational ends, a varied, strong and virile population, and in a picturesque history, there were ample forces for the expression of civic life in a city of striking individuality, one might almost say personality" $(1911,31)$. His tripartite prospect for Madison as a capital city, as an educational center, and as a place of residence gave rise to a complete garden city project with a very liberal provision of extensive waterfront parks and large open spaces. For Nolen, what was lacking in contemporary cities were garden and landscape features; and that therefore, particularly the university should pay more interest to the scientific, practical, and aesthetic value of nature. He wanted to plan not detached or isolated parks, each separate from the other, but a park system that would make a beautiful and ordered, free, organic city. design solution that combined the progressive ideal and the capitalist economic power into one area of practice. However, it was strongest in the countryside, and in particular, in small towns and suburbs. Many projects comparable to the European examples of green suburbs were designed in this period and became role models for many architects and planners. Of the many significant urbanists, John Nolen, an architect and a town planner of his period, certainly merits particular discussion (16). For Nolen, the architectural aesthetic was not the primary objective, and city planning was not merely a movement to make cities beautiful in a superficial sense. He believed, rather, that "the modern concept of 'beauty' was based on the social utility and functional performance of the result," thus "planning was a 'science' that permitted one to know the needs of the urban community and provide for them by creating services" (Dal Co, 1979, 214); and to raise a public spirit that required a set of changes in municipal regulations. For him, the large-scale urban surveys and the comprehensive urban plans, as well as the housing-reform programs, were necessary steps to providing that public spirit. In his opinion, financial and social conditions also largely affected his urbanism; however, Nolen's main focus was upon nature, "the closer a town plan adheres to the natural conditions, the more original and attractive it will be" $(1910,43)$. The garden city was not a fantastic project, but was rather an important instrument of modern urbanism through which the principal elements were streets and roads, waterways and waterfronts, parks, playgrounds and other public open spaces, and finally the public structures. The study of parks and open public spaces were his primary contribution, because he believed that public parks were "as a necessity of city life, a part of city plan, just as streets and schools are ... it is recognized that such facilities as parks afford are not only desirable, but increasingly necessary, in fact indispensable" $(1910,71)$. On January 26, 1909, the city of Madison invited Nolen to develop a comprehensive plan for the future growth and development of the city, as the capital of Wisconsin State and the home of its university (17). The Madison Project was a deliberate attempt to converge the vast green within the city, which in many respects related to the tradition of the romantic suburb. Along with his interest in the economics of planning and housing, his architectural style also became a means for his urbanism: "Quite beyond their architectural forms, they are unified plans in which architecture is significant only to the extent that it contributes to underlining the unity and continuity of the urban structure. Nolen's work indeed affirms that planning is not a task of individual and partial interventions, but an instrument for elaborating comprehensive urban designs, of which architecture is only a part, and not the most important" (Dal Co, 1979, 216).

Nolen's urbanism would influence several other projects across the country, in which Clarence Stein and Henry Wright were prominent among their counterparts in their creation. Although they followed a similar pattern in combining the natural elements with the physical layout, "their unique contribution to the garden city lay in the handling of traffic and pedestrian circulation through the so-called Radburn layout, which they developed for the garden city of the same name in 1928" in New Jersey (Hall, 1990, 123). For Stein and Wright, the traditional neighborhood was the essential element of their design concept, and the vitality of the neighborhood ideal as a political and a moral unit was practiced first in the model garden suburb of Forest Hill Gardens, developed in 1911, and would go on to become the locus for further design examples. A common place for the encouragement of community institutions, local shops 
18. The 1,202 family units were constructed between 1924 and 1928 as a continuous large-scale planning and design operation. "What really distinguished this residential development separated from the surrounding grid layout, was the creation of 'open spaces for natural green' within the various individual dwelling complexes, communal garden areas cut-off from the urban scene, which served greatly to stimulate the collective life of the community" (Dal Co, 1979, 239).

19. He entered the White House in 1933 , when the country was under a severe social and economic crisis; and he immediately began to exercise major conservation projects central to his progressive ideology -the Civilian Conservation Corps (CCC), the Soil Conservation Service (SCS), and the Tennessee Valley Authority (TVA) at that time were among the many New Deal programs designed to serve both the land and the country. For instance, the CCC as a public work program itself put nearly 3 million jobless young men to work. Like Theodore Roosevelt, Franklin Roosevelt utilized scientific planning procedures in the use of public lands and resources, believing that the planning was one of the most important tools of the federal government (Shabecoff, 1993). that served for each neighborhood, and local schools and playgrounds within walking distance were all carefully adopted to achieve a genuine neighborhood structure. Forest Hill Gardens was indeed an experiment in returning to an American tradition, that of the colonial village. As Wright emphasized in Rehousing Urban America of 1935, "the essential elements of modern community planning were already there, being the 'common' - or land held by the community around which the village was grouped; rational open spaces; exposure and protection for every house; [and] an orderly arrangement with due regard for human amenities" $(1935,33)$. The community ideal further became an important initiative for many projects, including Sunnyside, Radburn and Chattam Village. During the summer of 1923, Stein and Wright were commissioned to design a possible American example of the garden city principle. The first important trial came in 1924, when they took on an undeveloped 77-acre inner-city site located 5 miles from Manhattan, named Sunnyside Gardens. The project was developed around traffic-free superblocks, creating vast interior garden spaces. "These central garden spaces, found throughout Sunnyside with a combined length of nearly three-quarters of a mile, are the most distinctive contribution of this project to the technique of planning or housing in fairly congested urban areas" (Wright, 1935, 37). It was the housing within the green that allowed the designers to create a remarkable community activity area in the central space (18). Another prominent feature of Sunnyside was the standardization of technical installations, providing a design method that in turn lowered production costs without affecting the living comfort. The development of Sunnyside was distinctly experimental; however: "Though Sunnyside was a new figure carved within the hard shell of the city, it is not a garden town. There was still the desire to see what might be done in the United States" (Wright, 1935, 42). In 1928, a similar project was under way in Fairlawn, New Jersey, in the town of Radburn. If Sunnyside was an urban project, Radburn was a green town project, housing 25,000 inhabitants in an area where the traffic and the residential complexes were completely separated. The scheme, which can be hailed as Stein and Wright's greatest achievement, was designed in such a way that each superblock, composed of diverse building types, enclosed a continuous interior park, and this greenery formed the core of each complex. The shape of the block and that of the park, as well as the cul-de-sac layout derived from Sunnyside and from the English garden suburbs, provided an informal naturalness of architecturally modest row-houses clustered alongside short cul-de-sacs that were remote from the main arteries; and a central public space, containing pedestrian and bicycle paths, contributing to the creation of a sense of rural scenery in a fictitious metropolis.

This Radburn tradition would later be adopted as an important political tool in advancing experimental urbanism under the administration of Franklin Delano Roosevelt (19), and the architectural manifestation became very significant. The idea of a Greenbelt city, which was developed by Rexford Guy Tugwell, was believed to be the most authentic manipulation of this new urbanism. The theory of Outside the Cities that originally came from Howard's garden city scheme, known as the Greenbelt Town Program, became quite popular, and Roosevelt was one of the most outspoken defenders of the program. For some, it was not "an advocate of the back-to-the-land movement"; however, throughout the program, "he saw a definite place for an intermediate type between the urban and rural, namely a rural industrial group" (Arnold 1971:28). Although Tugwell's first proposal was for 3,000 new greenbelt cities, for political reasons 
20. "The unique planning feature of the greenbelt towns was of course, the greenbelt. Its purpose was to separate the town from surrounding built-up areas, to provide a land reserve for expansion of the community to its predetermined limits, and to provide a rural environment for the towns people" (Arnold, 1971, 92). the eventual program consisted of just three; Greenbelt-Maryland in Washington DC; Greenhills-Ohio in Cincinnati; and Greendale-Wisconsin in Milwaukee. These projects however, could hardly be compared with either the Soviet revolutionary or the traditional American examples, in that "they rather represented a solid Anglo-Saxon conservative standpoint because the great majority of the architects and engineers who directed the greenbelt town program were Republicans" (Arnold, 1971, 50)(20). The rural image in greenbelt towns was important. In Greendale, for instance, a collective farm where salaries were based on a share of the profits was strongly recommended by the planning team; and individual gardens were also provided for all. The idea of the neighborhood was the departure point, and the curvilinear streets and superblocks between them were carefully designed. However, Greendale planners preferred not to follow the curvilinear Radburn approach or the superblock idea, choosing to design more traditional streets and housing blocks in the Colonial Williamsburg style that followed the American colonial and European village pattern (Alanen and Eden, 1987). Nevertheless, what was common in those projects was the importance of the town center as a focal point of the community and the traffic system, which was designed in such a way that the through traffic in communities was separated from the residential streets by way of a peripheral highway that circumvented the neighborhoods. Finally, as also suggested by Arnold, "the most important feature of any community is its homes: they usually represent the most valuable physical property in the town (overwhelmingly so in residential suburbs) and are the buildings in which most of the family living is done" $(1971,98)$. As a leading New Deal planner, however, Tugwell came under bitter attack from Congress, the media and the financial sector, for whom "Tugwelltowns" represented the start of a political takeover, as it was believed that it imposed a socialist program. As a result, even though it was an important experience in the complete federal control over site selection, land purchase and construction management, the program was canceled in the mid-1930s.

\section{THE AMERICAN ANARCHISM: BACK TO THE AGRARIAN SPIRIT}

As the nation approached WWII, the overall policy on urbanism became larger in scale and more radical in content with the aim of developing an original synthesis of regionalism and the transcendentalist philosophy of nature. It was soon expressed as a comprehensive plan, based on analyses and interdisciplinary studies of all aspects of urbanism -economics, nature, geography and history- that would eventually structure the region as an entity. Developed by two anarchists, Bakunin, and later Kropotkin, urbanism on a larger scale proposed a new methodology in which the regional survey, the emphasis on traditional patterns and historical connections, was of the utmost importance. The region became more than a mere object of survey, as it was rather to provide a total reconstruction of social and political life. Kropotkin's belief, for instance, that society must rebuild itself on the basis of co-operation among free individuals was indeed a departure point. For Kropotkin, the twelfth century revolution in Europe, which had expressed itself in the local village community, urban fraternities and guilds, and the individual small self-governing states in medieval times, had been utterly abolished by the centralized states in the sixteenth century. However, the "popular-federalist-libertarian movement" was a new paradigm because, as he claimed, "industries of all kinds decentralize and are scattered all over the globe; and everywhere a variety, 
an integrated variety, of trades grows, instead of specialization" $(1974,38)$. The general trend of decentralization was in part due to the technological improvement that was to allow the modern industrial structures to be small in scale. The pure belief in the benefits of advanced technology was one of the most significant insights; and for some, the new age of industrial decentralization, the "neotechnic order," could lead to a new urban utopia. Cities in Evolution, published in 1905, was then a new paradigm with which urbanism on a larger scale and the green city ideal went hand in hand as a truly political expression of the New Deal Era (Geddes, 1968); however in sharp ideological contrast, the notion of regional planning soon became an agrarian matter that was once again in the hands of the southern intelligentsia. With a romantic pastoral view that was based on Medieval Europe or early New England, the Southern Agrarians at Vanderbilt University in Nashville, Tennessee were the most outspoken defenders of regional planning, voicing an opposition that was based on the ditching of northern industrialism in favor of an ideal life that promoted agriculture and small-scale home production. In fact, the quasi-mystical view of southern agrarian politics had a radical side: "Marxism was not sufficiently revolutionary, since it aimed to overcome capitalism with a capitalism of the left ... capitalism could be overcome solely by the diffusion of private property. This was the teaching of the Jeffersonian tradition, the very basis of America; the solution to the crisis of American civilization was the return to American culture" (Ciucci, 1979, 342). Their primary emphasis was on the decentralization of wealth and power, and the regeneration of the region's natural resources; while private property was also deemed important, not only for the maintaining of an economic system for the equitable distribution of well being, but also to revive the Jeffersonian legacy. It was then conceived as the nucleus of a comprehensive project for territorial development. Of the many projects, however, the Tennessee Valley Authority (TVA) was undeniably the greatest achievement of the New Deal Era. Located in eastern Appalachia, possibly the poorest part of America, the program was neither purely socialist nor romantic agrarian in character, although it had much in common with the early utopian communities. Rather, it turned out to be a successful example of the American grassroots movement in which the federal government worked co-operatively with local agencies.

Urbanism on a larger scale represented an important attempt to achieve a fragile balance between the American vision of nature and a nation that was becoming more and more capitalistic - a mythic domicile in which the idea of romantic nature would become fused with capitalist obsession. The agrarian ideology, replacing the urban-industrial sentiment, once again became a perfected example of a new social order with a political demand that gave rise to a genuine tradition of community; i.e., the distribution of land, the integration of agriculture with small industries and the decentralized autonomous government system became common points of reference. However, the progressive regionalists and the conservative agrarians were soon separated ideologically, as they proposed different political, social and economic perspectives. The progressive thought was much in favor of the legacy of the socialist ideal, whereas the conservative sentiment was dedicated to the premise of the traditional community based on the rights of the individual. The agrarian view was against the capitalist city and the industrial society, being rather devoted to the recovery of nature and a return to the land -the land of the frontier. The Southern intelligentsia believed that the poor conditions of rural life were 
21. The Muscle Shoals Project on the

Tennessee River in Alabama became a point of reference: as a linear city of 75 miles long, the idea of a community life and private workers' houses in small pieces of land and factories were organized and dispersed in nature to provide a synthesis of agriculture and industry. The city was designed to be self-sufficient and even all the facilities were part of the same industry. It was a new formation of production and consumption as well as a new form of relationship between the federal government and the private sectors. The resemblance between the socialist-anarchist proposals and the Muscle Shoals was, however, very striking; the integration of agriculture and factorywork developed by Kropotkin, Howard and Geddes became a conservative project in the hands of an American capitalist, Henry Ford. The entire project was in fact a genuine policy of industrial decentralization that vigorously aimed to control the working class since the worker was chained to his job through his land. Ford's urban project was never actually realized; however, his main objective to abandon the urban structure and create a model of life in the countryside became an ethos for many anti-urban agrarians, throughout the twentieth century.

22. His proposal overlaps, in this respect, with that of the Southern popular agrarian view: "a view of nature that was blended with a planned urban life as expressed through small houses, small industries, small schools, a small university, and small farms for 1,400 families, or more than 7,000 inhabitants. However, his essential insight was decentralization: if properly planned, he believed" cities could spread over the countryside and still not lose their "cohesion of efficiency" (Fishman, 1977, 122). being determined by the politics of the big cities, and that the solution to that social crisis, therefore, lay simply in free competition and the land ethic - in short, eighteenth-century laissez-faire. In 1940, the increasing role of the federal government came under scrutiny, with claims that a central government was principally contrary to the principles of the frontier culture. The agrarian ideology idealized the Arcadian myth once again, and then captured the contradiction between the reality of urban life and the dream of rural existence. The community, hence, gained its power from the American suburb, and soon became the ideal model for urban development, in that it offered a compromise between the city and the frontier. For instance, the Riverside Project and Oak Park in Chicago were two such communities that established forms of relationships that the city could not offer, and soon became places for the individual, and a myth in a country that was free and independent, yet collided with the urban reality. The exclusive individualism and the love of nature, which in fact revisited the Jeffersonian ideal "that government is best which governs least," was the locus of the agrarian ideology. Following Belloc's theories, agrarian intellectuals searched for a new discourse between the two extremes of his communist manifesto and the agrarian dream of rural-based capitalism. However, the middle road defined was indeed an ideological attempt not only to remove the Southern economic poverty, but also to avoid the awakening class-consciousness of the American proletariat, assuming that the middle road would create a classless, yet hierarchical, order. The agrarians enthusiastically embraced Turner's position on frontier culture regarding nature, that it was in the country, "the small provincial places of the South and the West, where the 'true' American spirit, uncontaminated by contact with the old world, was still conserved (Ciucci, 1979, 334)(21).

\section{EPILOGUE: A TRIAL FOR AN AGRARIAN METROPOLISM}

The dust-bowl crisis of the late 1920s, the Great Depression of 1929, the nationwide decline in agriculture, and the crisis of the traditional family due to massive migration to urban areas forced many to rethink urbanization. The Tennessee Valley Authority experiment of 1933, however, marked a significant change in the political agenda, as it opened a new path for real possibilities that was free from mere utopian hypotheses and became the milestone for all subsequent interventions. It was after the 1930s, however, with such programs as the reorganization of land-use, and the development of mass-housing projects that Frank Lloyd Wright began to work on his Broadacre City project in which his intention was to design an agrarian metropolis that he believed would offer a valid solution to the problems of industrial urbanism. Much has been written about this legendary American architect; nevertheless, a few remarks are necessary here in order to conclude our almost century-long narration. Broadacre City was essentially an urban Arcadian myth, a return to the Neo-Turnerian world of the frontier, and to a pre-bourgeois world that was uncorrupted by capitalist development. It was an attempt at the industrial and technological restructuring of rural areas, and as a perfected solution to the problems of the agrarian world (22). Wright adopted the basic principles of agrarian economics, in which the conflict between capital and labor was not fundamental to the capitalist society and could be overcome with equality in land ownership. He believed that the planned community would provide an environment in which this conflict would cease to exist and the community would protect the equitable distribution of land. For some, the community itself must have control of the land, however 
according to Wright it was individuality and the individual's absolute right to property that would provide the essence of a democratic community. Wright's Broadacre City also offered no distinction between the urban and rural in a bid to eliminate the fragments of modern life based on the capitalist mode of production. In this way, not only could the city be a natural feature of the surrounding landscape, but the bourgeois idea of the division of labor could also no longer be the dominant social structure.

Broadacre City was in fact a good representation of a lasting tradition from Howard's Green City, or Geddes' utopian town to Ford's city of Muscle Shoals. For Ciucci, Broadacre "embraces many of the utopian ideas of the nineteenth century ... that characterized the first Jeffersonian towns, such as Jeffersonville, or the towns of the frontier, particularly those of the Mormons" $(1979,363)$. In fact, Wright's proposal draws from mid-nineteenth urbanism, and yet also borrows from his contemporaries: Jefferson, Thoreau and Emerson, Roosevelt, the Southern Agrarian ideology, as well as the New Deal Regionalist ideal, were all brought together in a mythical place where the continental landscape was believed to overlap with the growing metropolitan urbanization. The proposal, however, exemplifies a complex political stage on which natural and cultural histories were performed through a variety of discursive formations and practices. This is in fact a history of ideas and, as suggested by Foucault, is based on opposing relations. It is a history of the relations that were established between "institutions, economic and social processes, behavioral patterns, systems of norms, techniques, types of classification, modes of characterization: and these relations are not presented in the object" $(1972,44)$. In a similar fashion, the relations between the American Arcadian vision and its boundless industrial capitalism require observation from a similar perspective - having a history in which the idyllic ideology and the culture of modernite are in a constant struggle, but can now be reformulated into one in which opposing ideological statements are of significance. Such statements, however, are not ideal or timeless, and in Foucault's own words, are rather a system of unity and discontinuity that require a critical inquiry, as they possess a complex form of history (1972).

\section{REFERENCES}

ABBOTT, C. (1981) The New Urban America, Growth and Politics in Sunbelt Cities, The University of North Carolina Press, Chapel Hill.

ALANEN, A. R. and EDEN, J. A. (1987) Main Street Ready-Made: The New Deal Community of Greendale, Wisconsin, The State Historical Society of Wisconsin, Madison.

ALLEN, I. L. (1977) New Towns and the Suburban Dream, Ideology and Utopia in Planning and Development, Kennikat Press, London.

ANDREWS, W. (1967) Social History of American Architecture, Architecture, Ambition and Americans, The Free Press, New York.

ARNOLD, L. J. (1971) The New Deal in the Suburbs, A History of the Greenbelt Town Program 1935-1954, Ohio State University Press, Ohio.

BAKER, A. R. H. (1992) Introduction: On Ideology and Landscape, in Ideology and Landscape in Historical Perspective: Essays on the Meanings of Some Places, eds. A. Baker, R. H. Alan, G. Biger, Cambridge University Press, Cambridge;1-14. 
BALDASSARE, M. (1986) Trouble in Paradise, The Suburban Transformation in America, Columbia University Press, New York.

BARTH, G. (1990) Fleeting Moments: Nature and Culture in American History, Oxford University Press, New York, Oxford.

BEARD, C. A., BEARD, M. R. (1968) The Beard's New Basic History of the United States Doubleday and Company, Inc., Garden City, New York.

BEARD, C. A. (1949) Economic Origins of Jeffersonian Democracy, The MacMillan Company, New York.

BEAUREGARD, R. (1989) Postwar Spatial Transformation, in Atop the Urban Hierarchy, Rowman and Littlefield Publishers; 1-44.

BENDER, T. (1975) Toward an Urban Vision, Ideas and Institutions in Nineteenth-Century America, The University Press of Kentucky, Kentucky.

BRIDENBAUGH, C. (1955) Cities in Revolt, Urban Life in America, 1743-1776, Alfred A. Knopf, New York.

BRIDENBAUGH, C. (1938) Cities in the Wilderness, The First Century of Urban Life in America 1625-1742, The Ronald Press Company, New York.

CIUCCI, G. (1979) The City in Agrarian Ideology and Frank Lloyd Wright: Origins and Development of Broadacres, The American City, From the Civil War to the New Deal, trs., B. L. La Penta, The MIT Press, Cambridge, Massachusetts; 293-376.

COSGROVE, D. E. (1984) Social Formation and Symbolic Landscape, Croom Helm Press, London, Sydney.

COSGROVE, D: E. (1984) Social Formation and Symbolic Landscape, Croom Helm, London and Sydney.

CRONON, W. (1992) Nature's Metropolis, Chicago and the Great West, Norton and Company, New York and London.

CURTI, M. (1980) Human Nature in American Thought, A History, The University of Wisconsin Press, Madison.

DAL CO, F. (1979) From Parks to the Region: Progressive Ideology and the Reform of the American City, The American City, From the Civil War to the New Deal, tr. by B. L. La Penta, The MIT Press, Cambridge, Massachusetts; 143-261.

DONALDSON, S. (1969) The Suburban Myth, Columbia University Press, New York and London.

DONALDSON, S. (1977) City and Country: Marriage Proposal, in New Towns and the Suburban Dream, Ideology and Utopia in Planning and Development. ed. by I. L. Allen, National University PublicationsKennikat Press, Port Washington, New York and London.

DOWNING, A. J. (1991) Landscape Gardening and Rural Architecture, Dover Publications, Inc., New York.

EDWARDS, A. M. (1981) The Design of Suburbia: A Critical Study in Environmental History, Pembridge Press, London.

FEIN, A. (1972) Frederick Law Olmsted and the American Environmental Tradition, George Braziller Inc., New York. 
FISHER, I. D. (1986) Frederick Law Olmsted and the City Planning Movement in the United States, UMI Research Press, Ann Arbor, Michigan.

FISHMAN, R. (1987) Bourgeois Utopias: The Rise and Fall of Suburbia, Basic Books, Inc., Publishers, New York.

FISHMAN, R. (1977) Urban Utopias in the Twentieth Century: Ebenezer Howard, Frank Lloyd Wright, and Le Corbusier, Basic Books, Inc., Publishers, New York.

FOUCAULT, M. (1972) The Archaeology of Knowledge and The Discourse on Language, Pantheon Books, New York.

GEDDES, P. (1968) Cities in Evolution, An Introduction to the Town Planning Movement and to the Study of Civics, Howard Fertig, Inc., New York.

GREIDER, T., LORRAINE, G. (1994) Landscapes: The Social Construction of Nature and the Environment, Rural Sociology, 59 (1) 1-24.

HADDEN, J. K., BARTON, J. (1977) An Image That Will not Die: Thoughts on the History of Anti-Urban Ideology, in New Towns and the Suburban Dream, Ideology and Utopia in Planning, eds. I. L. Allen, National University Publications-Kennikat Press, Port Washington, New York and London.

HALL, P. (1990) Cities of Tomorrow, Basil Blackwell Inc., Cambridge, Massachusetts.

HOWARD, E. (1966) Garden Cities of To-morrow, The MIT Press, Cambridge, Massachusetts and London.

JACOBS, J. (1961) The Death and Life of Great American Cities, Random House, New York.

JACKSON, K. T. (1987) Crabgrass Frontier, The Suburbanization of the United States, Oxford University Press, New York and London.

KAMMEN, M. (1974) People of Paradox, An Inquiry Concerning the Origins of American Civilization, Alfred A. Knopf, New York.

KASARDA, J. (1988) Economic Restructuring and America's Urban Dilemma, in The Metropolis Era: World of Giant Cities, eds., J. Kasarda, Sage Publications, v: I; 69-83.

KROPOTKIN, P. (1974) Fields, Factories and Workshops Tomorrow, George Allen and Unwin Ltd., London.

KUNSTLER, J. H. (1994) The Geography of Nowhere, The Rise and Decline of America's Man-Made Landscape, A Touchstone Book, Published by Simon and Schuster, New York and London.

MARX, L. (1967) The Machine in the Garden, Technology and the Pastoral Ideal in America, Oxford University Press, London, Oxford, New York.

MILLER, P. (1981) The American Transcendentalists, The John Hopkins University Press, Baltimore and London.

NOLEN, J. (1919) New Ideals in the Planning of Cities, Towns, and Villages, American City Bureau, New York City.

NOLEN, J. (1911) Madison: A Model City, Cantwell Printing Company, Madison, Wisconsin. 
O'CONNELL, B J. (1989) The Federal Role in the Suburban Boom, in Suburbia Re-examined, eds., B. Kelly, M. Greenswood Press, New York and London.

REPS, J. (1989) Town Planning in Frontier America, University of Missouri Press, Columbia and London.

ROPER, L. W. (1983) FLO, A Biography Frederick Law Olmsted, The John Hopkins University Press, Baltimore and London.

ROWE, P. G. (1991) Making A Middle Landscape, The MIT Press, Cambridge, Massachusetts.

RUSK, D. (1993) Cities Without Suburbs, Woodrow Wilson Center Press, Baltimore, MD.

SARGIN, G. A. (2000) Nature of Resistance and Counter-hegemony in Postindustrial Society, in Nature as Space: (re) Understanding Nature and the Natural Environments, ed. by G. A. Sargın, METU MfY Press, Ankara; 59-79.

SARGIN, G. A. (1997) Myth, Ideology, and Hegemony: The Political Syntax of American Environmental Design Tradition, METU JFA, v:17, n: $1-2 ; 25-42$.

SARGIN, G. A. (1996) Myth and Ideology in Middle Landscape: Politics in the Perception of Nature in American Environmental Design Discourse, Unpublished Ph.D. Thesis, University of Wisconsin at Madison, Madison.

SCHAFFER, D. (1982) Garden Cities for America, The Radburn Experience, The Temple University Press, Philadelphia.

SELLERS, D. (1991) Settlement Patterns in America, Progressive Architecture, n: 3; 86-7.

SHABECOFF, P. (1993) A Fierce Green Fire, The American Environmental Movement, Hill and Wang, New York.

SHORT, R. J. (1991) Imagined Country, Society, Culture and Environment, Routledge, London and New York.

STEWARD, I. R. (1973) Central Park 1851-1871, Urbanization and Environmental Planning in New York City, Unpublished Ph.D. Thesis, Faculty of the Graduate School of Cornell University, Ithaca, New York.

THOREAU, H. D. (2004) Walden, Henry David Thoreau, Beacon Press, Boston.

TOCQUEVILLE, A. de. (1981) Democracy in America, Modern Library College Editions, New York.

TURNER, F. J. (1940) The Frontier in American History, Henry Holt and Company, New York.

WRIGHT, H. (1935) Rehousing Urban America, Columbia University Press, New York, Morningside Heights. 
Alınd1: 06.12.2010; Son Metin: 22.03.2011

Anahtar Sözcükler: Doğa-kent karşıtlığı, Arkadyan vizyon; endüstriyel kapitalizm metropolis ve kültür politikaları; $\mathrm{ABD}$ bağlamında kentleşme.

\section{İKINCİ DOĞAYI ÜRETMEK: KENTSEL ALGIDA KÜLTÜREL POLİTIKKALARIN ELEŞTİi̇̇İNE DOĞRU / ABD BAĞLAMI, 1850-1940}

Çevresel dönüşüm gerçekte, doğa ve kültür arasında sürekliliği olan şiddetli bir gerilime işaret eder; bir diğer deyişle, toplumsal fayda adına birinci doğanın siyasi bir program ve ideolojik araçlar vasıtasıyla üretimi, bir tür çatışma anlamına gelir ve bu, Marks'ın ikinci doğa tanımıyla örtüşür. Burada özellikle altı çizilmesi gereken olgu, kentleşmenin, doğa ve kültür arasında süregelen mücadelenin hem öznesi hem de nesnesi konumunda olduğudur. Yazımız bu noktada, yukarıda özetlediğimiz kuramsal çerçeveye bağlı kalarak, İç-savaş ve İkinci Dünya Savaşı arasında, bu süreci örgütleyen çok özel bir bağlama, Amerikan kentleşme tarihine bakarak, doğa ve kültür çatışmasının mekan üzerinden okunabilirliğini sınamaya çalışmaktadır. Kentleşmenin araçsallaştırılmasının meşrulaştırılması süresince ortaya konulan söylemler ve farklı ideolojik arkitiplerin iki savaş arasındaki ütopyan tezahürleri, araştırmamızın örneklemelerini içermektedir.

Doğa ve kültür arasındaki çatışma, temelde Arkadyan bir ideolojik yapılanma ile, 19. Yüzyılın ikinci yarısından itibaren kendisini tek egemen üretim modu olarak kabul ettiren endüstriyel-kapitalist olgu arasındadır. Daha önceleri, neredeyse popüler bir anlatıya dönüşen "öncü kültürü" (frontier culture), kapitalist üretimin baskın tavrı karşısında yeniden yapılanarak, alışık olmadık kentleşme söylem ve mekansal uygulamaların oluşumuna yol açar ve özellikle, endüstrileşmeye paralel gelişen yeni siyasa, "metropolitan" bir algıyı ve ona takılı kültürel kodları, gündelik hayat ve üst-kültür alanlarına da taşır. Burada, yeni disipliner yapılanmalar ile mesleki söylem ve uygulama alanlarının, İkinci Dünya Savaşı başlarına kadar ne denli etkin olduğunun altı çizilmelidir: Siyasi erkin, doğa ve kültür çatışmasına ilişkin ideolojik tercih ve yaptırımları, söylemsel ve yasal olanın çok ötesine taşınmış; mimarlık ve planlama disiplinleri aracılığı ile neredeyse birer sosyal mühendislik projelerine dönüşmüştür. Doğa, ilkesel olarak ahlaki bir dayanak; buna karşılık metropolis, egemen siyasetin ideolojik mekanıdır: Ahlaki dayanak ile ideolojik mekan arasında süregelen yüzyıllık savaş ise farklı ütopyalar aracılığı ile meşruiyet zemini elde etme uğraşısındadır.

Bu noktada metin, farklı dönemlerde ileri sürelen, yeri geldiğinde de siyasi iradenin yaptırımları ile uygulanan söz konusu mekansal ütopyaları tartışmaktadır. Mekansal ütopyaların, kültür politikaları ile süregelen ilişkisi çok önemlidir. Sonuçta bilinmesi gereken şey, kültür üzerinden yürütülen siyasetin, mimarlık ve özellikle kent mimarlığını, üretim ilişkileri bağlamında doğrudan etkilediğidir. Metinde ileri sürülen sav da dolayısıyla, bir görüşün bir başka görüşe görece üstünlüğünün çok ötesindedir: Söylemsel formasyon ve pratikler arasında süregelen çatışma üzerinden mekan tarihlerinin irdelenmesi, eleştirel bir okuma yapılabilmesi açısından önemli ipuçları sunmaktadır.

GÜVEN ARİF SARGIN; B.ARCH, M.Sc., PhD.

Completed his doctoral studies at UW-Madison in Urban and Environmental History and Theory; teaches on social and political aspects of space as Associate Professor in the Department of Architecture at METU, where he is the Head of the Department of Architecture since 2007. Along with his contribution to architectural design studios, runs graduate studios on urban architecture. $\underline{\text { sargin@metu.edu.tr }}$ 